\title{
Permafrost of the east Siberian Arctic shelf and coastal lowlands
}

\author{
N.N. Romanovskii ${ }^{\mathrm{a}, *}$, H.-W. Hubberten ${ }^{\mathrm{b}}$, A.V. Gavrilov ${ }^{\mathrm{a}}$, \\ V.E. Tumskoy ${ }^{\mathrm{c}}$, A.L. Kholodov ${ }^{\mathrm{d}}$ \\ ${ }^{\text {a }}$ Faculty of Geology, Moscow State University, Moscow 119899, Russia \\ ${ }^{\mathrm{b}}$ Alfred Wegener Institute of Marine and Polar Research, Potsdam, Germany \\ ${ }^{\mathrm{c}}$ Faculty of Geography, Moscow State University, Russia \\ ${ }^{\mathrm{d}}$ Institute of Physical-Chemical \& Biological Problem of Soil Science, RAS, Pushchino, Russia
}

\begin{abstract}
In the past decade, within the framework of joint Russian-German marine and terrestrial studies on the Arctic shelf, New Siberian Islands, and coastal lowlands of the Laptev and East Siberian seas, fundamentally new data have been obtained on terrestrial and offshore permafrost in this area. Field and laboratory investigations supplemented with numerical modeling and generalization of the results of numerous geological surveys, exploratory works, and scientific researches performed in previous years have made it possible to revise existing knowledge about the distribution, thickness, physical state, and history of development of terrestrial and offshore permafrost in the East Siberian part of the Arctic. The main results of these studies and their interpretation are discussed in this paper.
\end{abstract}

(C) 2003 Elsevier Ltd. All rights reserved.

\section{Introduction}

The shelf and coastal lowlands of the Laptev and East Siberian seas (Fig. 1) represent a virtually flat accumulative plain. The largest part of the shelf has sea depths of less than $60 \mathrm{~m}$. The shelf edge (transition to the continental slope) lies at a distance of $400-800 \mathrm{~km}$ from the modern shoreline; sea depths in this area range from 80 to $100 \mathrm{~m}$.

\section{Relic offshore permafrost: methods and the main results of its study}

Up to the beginning of the 1990s, it was generally believed that relic offshore permafrost had a limited distribution within the shelf of the Laptev and East Siberian seas. These notions were analyzed in detail by Gavrilov et al. (2001). It was also believed that the thickness of submarine (offshore) relic permafrost was considerably lower than that of permafrost within coastal lowlands shown on the Geocryological Map of the USSR, 1:2.5M scale (1996). 89.

*Corresponding author. Tel.: + 7-95-939-1937; fax: + 7-95-932-88-

E-mail address: nromanovsky@online.ru (N.N. Romanovskii).
In the 1990s, the results of joint Russian-German seismo-acoustic sounding and sampling of bottom sediments in the Laptev Sea proved that relic offshore permafrost is widespread all over the shelf. It was also found that the permafrost table has an uneven surface (Romanovskii et al., 1998a,b). The upper acoustic boundary was interpreted as a surface of ice-bearing permafrost. This conclusion was supported by drilling data within the shelf performed in September 2000 (Kassens et al., 2000). Deep seismic sounding on the Laptev Sea shelf (to the north and northwest of Kotel'nyi Island) confirmed the presence of permafrost in this area. The second acoustic boundary was detected at depths from 300 to $700 \mathrm{~m}$; this boundary was attributed to the bottom of the ice-bonded permafrost (Hinz et al., 1998).

\subsection{Methods}

Mathematical modeling was applied by the authors in order to study the distribution and thickness of the relic offshore permafrost and trace its evolution in the Pleistocene. This modeling was based on a series of computer programs created by Tipenko et al. (1999, 2001). Paleogeographic scenarios for the models were developed with due account of global climatic changes 


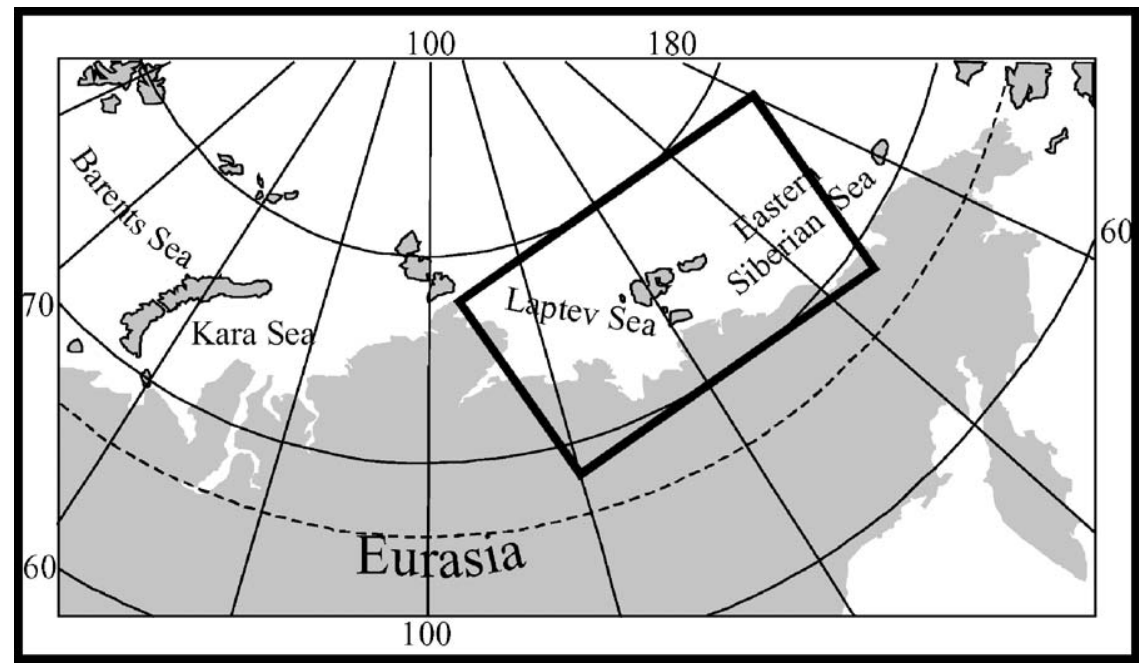

Fig. 1. Schematic map of east Siberian part of the Arctic.

and existing notions about the predominantly glacialeustatic sea-level fluctuations in the Arctic Basin. The curves characterizing these fluctuations were taken from Chappell et al. (1996) and Fairbanks (1989). The East Siberian shelf was not glaciated hence, did not experience glacial-isostatic movements. Along with this, neotectonic movements in the studied region consisted predominantly descending character accompanied by the accumulation of fine-grained sediments of both marine and continental origins. In the periods of sea regressions, aggradation of permafrost took place along with the accumulation of continental syncryogenic deposits with a high ice content within coastal lowlands and the emerged part of the shelf. These deposits are known as the Ice Complex (IC). The volumetric ice content in the IC reaches $90 \%$, and the IC thickness ranges from several meters on uplands to $60-80 \mathrm{~m}$ in neotectonic depressions. Upon sea transgressions, permafrost within the submerged part of the shelf degradated. It is important that the seawater temperature in the studied seas is below $0^{\circ} \mathrm{C}$. To a large extent, this is explained by the specific cooling effect of the Great Siberian openwater area with the formation of a thin and slightly saline sea ice and dense low-temperature brines (Churun and Timochov, 1995). The descending movement of these brines exerts a cooling effect on the near-bottom seawater layers. Thus, the thawing of frozen fresh-water sediments under the impact of low-temperature seawater proceeds very slowly. As a result, the degradation of the offshore permafrost is mainly manifested by a rise in the frozen ground temperature between $-1.0^{\circ} \mathrm{C}$ and $-2.0^{\circ} \mathrm{C}$ and the transition of low-temperature ice-bonded permafrost to relic offshore permafrost.

While modeling permafrost evolution in the studied region, we also took into account latitudinal zonality of the mean annual ground temperature $\left(t_{\mathrm{m}}\right)$. It was assumed that this zonality in the past was similar to the present temperature zonality, i.e., that $t_{\mathrm{m}}$ decreased by about $1.5^{\circ} \mathrm{C}$ per $1^{\circ}$ of northward latitude (Geocryology of the USSR, 1989). Geological sections of the Laptev Sea shelf obtained by Drachev et al. (1999) on the basis of the results of deep seismic sounding, were used as a geological basis for the modeling. Physical and thermal properties of the rocks in our models were taken from Balobaev (1991). We selected those values of rock properties that corresponded to extreme values of the permafrost thickness. Thus, maximum and minimum values of the rock density, water (ice) content, and other properties were tested in the models. It was taken into account that the freezing of saline sea deposits occurs over a certain range of temperatures, depending on the salinity. As a result, we distinguished between the layers of frozen rocks proper and ice-free cryotic deposits with subzero temperatures down to $-2.0^{\circ} \mathrm{C}$ (Fig. 2). In turn, frozen layers were separated into ice bonded and ice bearing permafrost. Ice bonded permafrost has low negative temperature and water in the form of ground ice and bonded water. In contrast ice bearing permafrost temperature is in the freezing-thawing range; ground ice is present in pores of deposits and rocks simultaneously with free and bonded water.

Data on the geothermal heat flux $q_{\mathrm{g}}$ were used as boundary conditions in the models; for the shelf, the $q_{\mathrm{g}}$ values were assumed to be equal to the values typical of analogous geological structures on the continent (Veselov and Lipina, 1983). For rift zones, these values were increased twofold as compared with undisturbed tectonic blocks (Lysak, 1988).

\subsection{Results}

The results of the modeling of offshore permafrost made it possible to suggest a new hypothesis for its evolution. It was established that the degradation of 


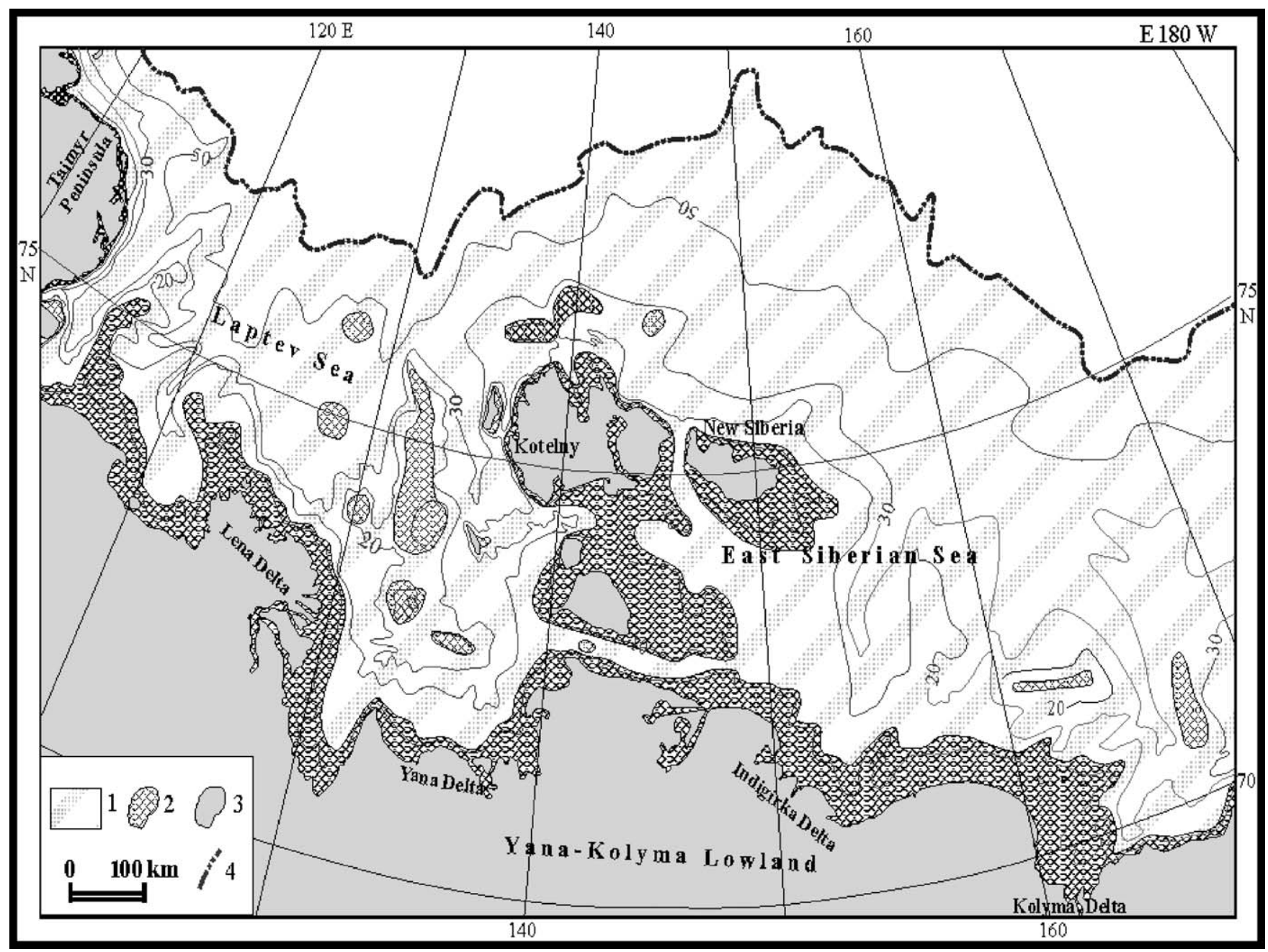

Fig. 2. Distribution ice-bearing permafrost and ice bonded permafrost on the East Arctic shelf. Submarine permafrost: (1) ice bearing; (2) ice bonded; (3) subaerial ice bonded permafrost; and (4) shelf edge (results of modelling).

offshore permafrost upon the submergence of the shelf is accompanied by the formation of a gradient-less temperature field; the thawing of relic permafrost occurs from the bottom under the influence of the geothermal heat flux, rather than from the top. Thus the rate of permafrost thawing is proportional to the $q_{\mathrm{g}}$ value. As a result, by the end of transgression stages, lithosphere blocks with different $q_{\mathrm{g}}$ values have different thickness of the preserved relic permafrost. The lower the geothermal flux, the greater thickness of the permafrost. In the areas with high values of $q_{\mathrm{g}}$ $\left(70-100 \mathrm{~mW} / \mathrm{m}^{2}\right)$ typical of rift zones, open taliks can be formed. Thus differences in the permafrost thickness are much greater at the end of transgression stages than at the end of regression stages characterized by the general aggradation of the permafrost that reaches the maximum thickness. In other words, the degree of contrast in the thickness of permafrost increases in the end of transgression stages, especially in rift zones (Fig. 3).
To study the modern state of relic offshore permafrost, the dynamics of the permafrost temperature field was modeled with due account for the fact that freezingthawing phenomena may occur within a certain range of temperatures. The results of this modeling showed that ice bearing permafrost occupies the largest part of the shelf in the Laptev and East Siberian seas (Fig. 2). Ice bonded permafrost is only present near the coast and in places on the former islands composed of the IC deposits. According to the modeling results, the time required for the transformation of the ice bonded permafrost into the ice bearing permafrost is assessed at several hundred to several thousand years.

The modeling of the dynamics of the temperature fields within the shelf was performed for one and for four climatic and glacial-eustatic cycles (i.e., for the last 400,000 years). The paleo-geographic scenario for the modeling was derived from recent ice-core data obtained at the Vostok station in Antarctica (Petit et al., 1999). These data were adapted for the studied region on the 


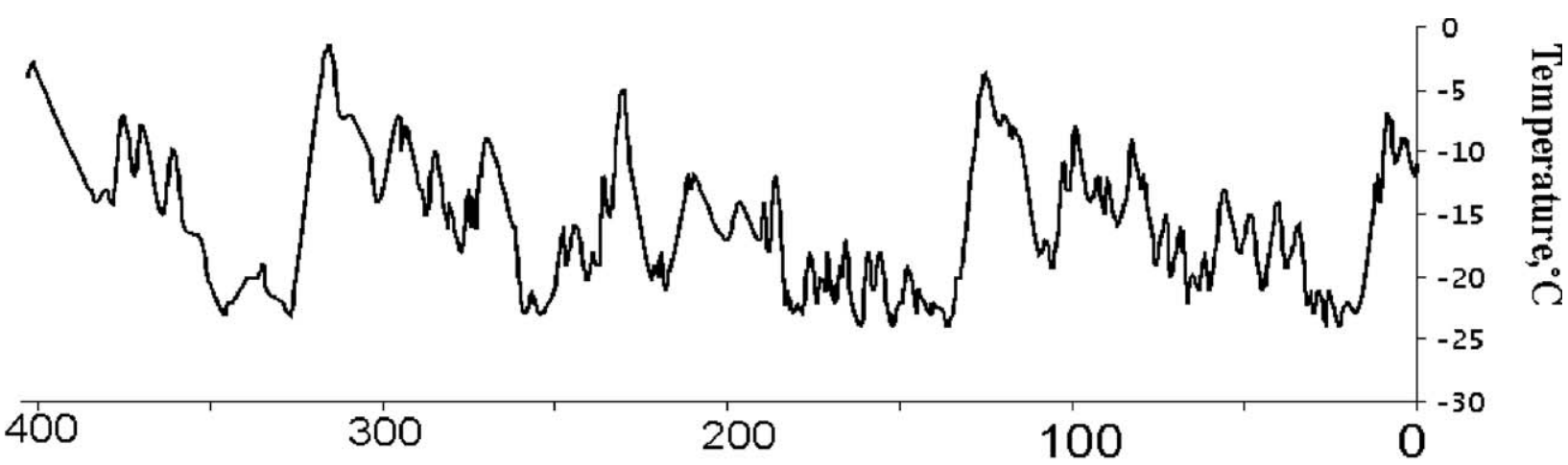

Time, kyr.b.p.

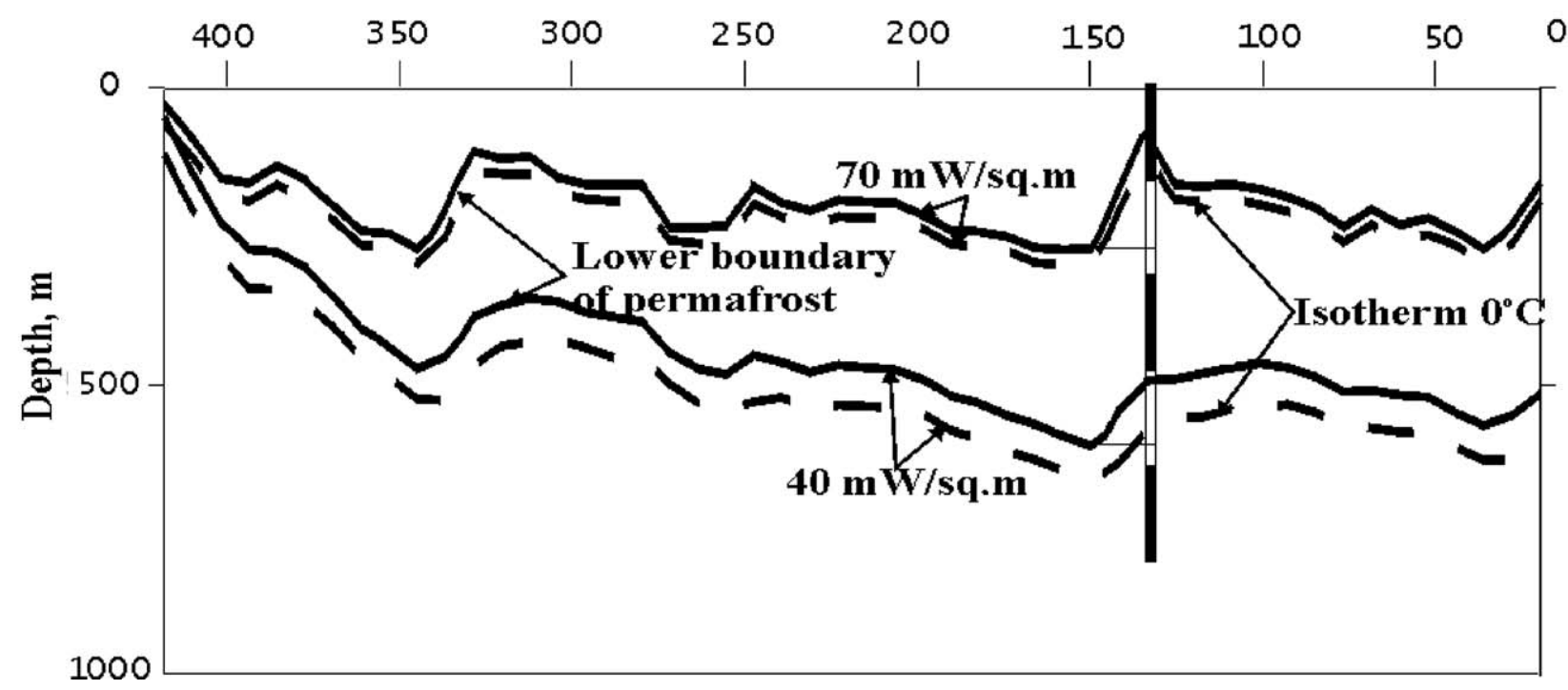

Fig. 3. Example of dynamic of mean annual ground temperature (upper figure) and of lower boundary of permafrost and isotherm $0^{\circ} \mathrm{C}$ (lower figure) during the last $400 \mathrm{kyr}$. due to different values of geothermal heat flux. Yakutian coastal lowlands, latitude $71^{\circ} \mathrm{N}$ (results of modelling).

basis of numerous paleo-geographic reconstructions for northeastern Yakutia (Gavrilov and Tumskoy, 2000). The adapted data were used for setting upper boundary conditions during the modeling.

The modeling for the four full cycles has shown that the offshore permafrost has been continuously preserved within the relatively shallow (50-60 m below sea level) part of the shelf beyond the rift zones (upon the $q_{\mathrm{g}}$ values of up to $70 \mathrm{~mW} / \mathrm{m}^{2}$ ). At greater depths, the offshore permafrost was completely thawed in the periods of maximal transgressions; relatively thin ice bearing permafrost could only be preserved in blocks of the lithosphere with low $q_{\mathrm{g}}$ values (see Fig. 4). At present, continuous relic offshore permafrost exists within the shelf with sea depths of up to $60 \mathrm{~m}$. This permafrost is being subjected to thawing from the bottom. At greater sea depths, the presence of isolated relic offshore permafrost can still be expected. In the rift zones with $q_{\mathrm{g}}$ values above $100 \mathrm{~mW} / \mathrm{m}^{2}$, open taliks should exist. Most probably, these taliks have a local character. They may serve for the discharge of groundwater and, probably, the emission of climate relevant gases $\left(\right.$ like $\mathrm{CH}_{4}$ ) from the layers under the permafrost.

Another kind of open taliks can be expected under the beds of paleo-rivers within the submerged shelf. However, open taliks could only be formed under the largest rivers. Even at the present time, which is much warmer than the Late Pleistocene Climate Minimum (Sartan cryochron, $20 \mathrm{kyr} \mathrm{BP}$ ), open taliks in the northern part of the terrestrial permafrost are restricted to the channel beds of Lena, Indigirka, and Yana rivers. In the paleovalleys of these rivers within the shelf zone, open taliks could be formed under the river channel beds rather than under the entire valleys. Thus, these taliks should have a narrow and elongated shape. Relatively small rivers with catchments lying within the permafrost zone (such as Khatanga, Olenek, Khroma, Omoloi, etc.) were completely frozen in the winter during the Late Pleistocene Minimum (Sartan cryochron). Therefore, the existence of open taliks in their paleo-valleys within the shelf is not expected. 


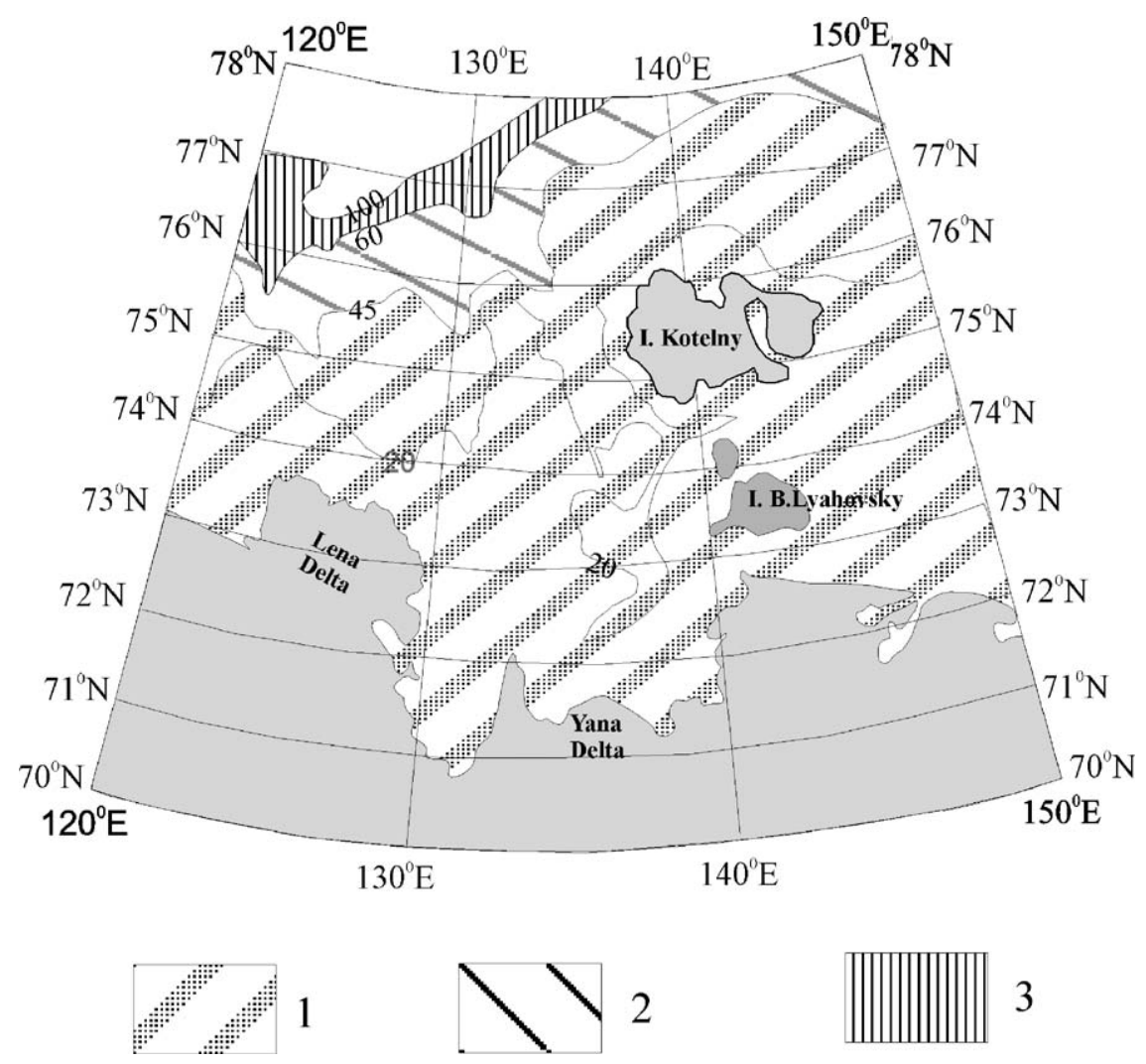

Fig. 4. Schematic map of the permafrost age on the shelf of Laptev Sea: (1) zone where permafrost exists at least during the last $400 \mathrm{kyr}$; (2) zone where degradation of permafrost took place during thermochrones on the sites with geothermal heat flux more then $60 \mathrm{~mW} / \mathrm{m}^{2}$; and $(3)$ zone, where permafrost have complete degraded during transgressions (results of modelling).

The schematic map of the thickness of offshore permafrost derived from the modeling at $q_{\mathrm{g}}=45 \mathrm{~mW} /$ $\mathrm{m}^{2}$ is shown in Fig. 5. As seen from this map, the most important factor controlling the thickness of relic offshore permafrost is the sea depth (provided that the geothermal flux is a constant). This factor dictates the duration of ground freezing during regressions and drying of the shelf, as well as the duration of permafrost degradation during marine transgressions. The latitudinal zonality of $t_{\mathrm{ma}}$ is a less significant factor. The greatest thickness of the offshore permafrost (500$600 \mathrm{~m}$ ) resulting from the influence of both factors is typical of shallow-water areas around the New Siberian Islands.

\section{The concept of shelf development in the Late Pleistocene and Holocene}

As mentioned above, the table of relic offshore permafrost has an uneven topography. Within sandy shoals at sea depths up to $20 \mathrm{~m}$, permafrost with ground ice is overlain by a relatively thin $(2-3 \mathrm{~m})$ layer of unconsolidated cryotic sediments, predominantly of marine genesis. At the same time, there are many places within the inner part of the shelf (at sea depths up to $30-40 \mathrm{~m}$ ) and in the straits separating the New Siberian Islands, the permafrost table lies at a depth of $100 \mathrm{~m}$ and more from the sea floor. In the context of our theory of the development of the shelf in the Late Pleistocene and Holocene (Romanovskii et al., 1999), this phenomenon can be explained in the following manner.

During the Late Pleistocene regression, sediments of the IC were accumulated on the surface of the exposed part of the shelf. The IC is still widespread on New Siberian Islands, coastal lowlands, and on some small islands (Mostakh, Makar, Shelonskie Islands) near the shore (within the Buor-Khaya and Yana bays). Owing to a very high ice content $(80-98 \mathrm{vol} \%)$, the IC is very susceptible to climatic changes.

At the end of the Late Pleistocene, a series of shortterm warming phases induced a rapid degradation of the IC. The most significant role in this natural process was played by the IC thawing with the formation of numerous thermokarst lakes. Available radiocarbon dates and the results of mathematical simulation (Kaplina and Lozhkin, 1979; Romanovskii et al., 2000; Tumskoy, 2002) have shown that the beginning of thermokarst processes was confined to the Bølling and Allerød phases (13-12 ka BP). According to our data, the process of extensive thermokarst development with 


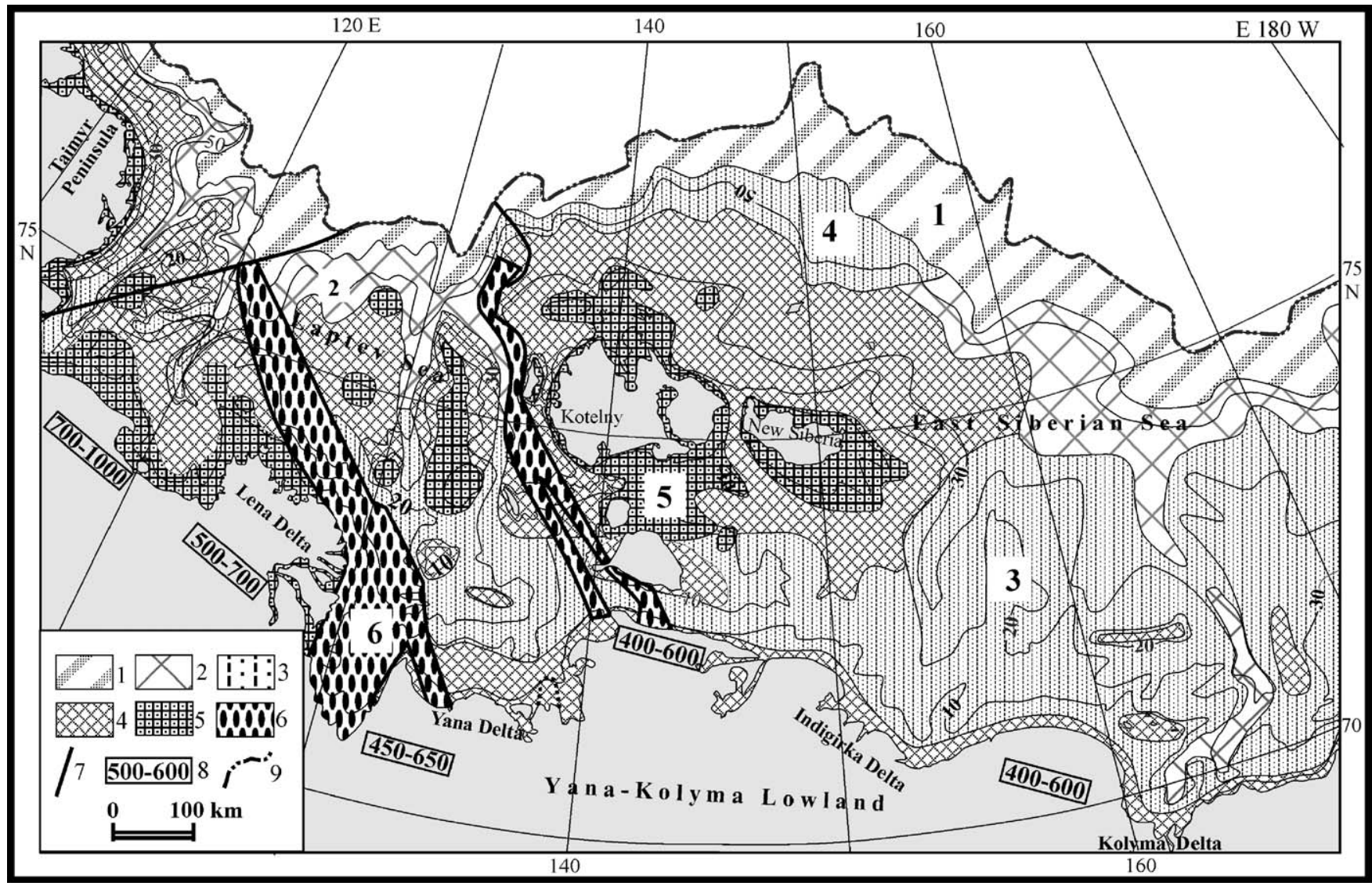

Fig. 5. The schematic map of the offshore permafrost thickness (result of the modeling at $q_{\mathrm{g}}=45 \mathrm{~mW} / \mathrm{m}^{2}$ ). Submarine permafrost thickness: (1) to $100 \mathrm{~m}$; (2) from 200 to $300 \mathrm{~m}$; (3) from 300 to $400 \mathrm{~m}$; (4) from 400 to $500 \mathrm{~m}$; (5) from 500 to $600 \mathrm{~m}$; (6) from 200 to $600 \mathrm{~m}$ (within the rifts); (7) main tectonic faults with permafrost thickness less then $200 \mathrm{~m}$ (zones of possible open taliks); (8) thickness of subaeral permafrost; and (9) shelf edge (results of modelling).

deepening and widening of thermokarst lakes ended about 9-7 ka BP. However, the deepening of taliks under the thermokarst lakes could proceed longer.

About $12 \mathrm{ka} \mathrm{BP}$, the shelf was still virtually exposed; by $9-8 \mathrm{ka} \mathrm{BP}$ the shoreline corresponded to the modern contour line of $31 \mathrm{~m}$ below sea level (Bauch et al., 1999). Therefore, active formation of thermokarst lakes on the shelf preceded the period of its submergence. The transgressing sea inundated the area with the already formed thermokarst topography, including thermokarst lakes and drained thermokarst depressions known under the Yakutian name "alases." With an inland shift of the shoreline, thermokarst lakes and alases were turned into sea bays that may be called "thermokarst lagoons". These "lagoons" were separated by elongated residual elevations of the surface topography of the IC forming peninsulas and capes. Some of these formations are still present along the shore, e.g., the Bykovskii Peninsula that separates the Lena Delta from the Tiksi Bay.

The inundation of thermokarst depressions by the sea resulted in a much higher sinuosity of the shoreline. In turn, this could not but enhance the total effect of thermal abrasion of the shores composed of the IC deposits. Somewhat later (approximately $9 \mathrm{ka} \mathrm{BP}$ ), when thermokarst lakes and lagoons reached the maximum stage of their development, the discharge of organic and mineral sediments onto the outer part of the shelf and on the continental slope decreased considerably (Bauch et al., 1999), in spite of the active thermal abrasion. This paradoxical phenomenon is explained by the fact that thermokarst depressions and lagoons served as traps for the abraded sediments (Romanovskii and Hubberten, 2001). An important consequence of these processes was a dramatic increase in the rate of transgression. Within the last 11,000 years, the shoreline shifted its position in a southward direction by $300-800 \mathrm{~km}$. The transgression was accompanied by the transformation of the residual IC formations separating thermokarst lakes and "lagoons" into elongated peninsulas and then islands composed of the IC sediments. The transformation of a peninsula into an island can be observed nowadays on the Bykovskii Peninsula (Fig. 6). Active thermal erosion is destroying the neck connecting this peninsula with the continent. It can be assumed that, during the Holocene, the shelf zone near the coast was complicated by 


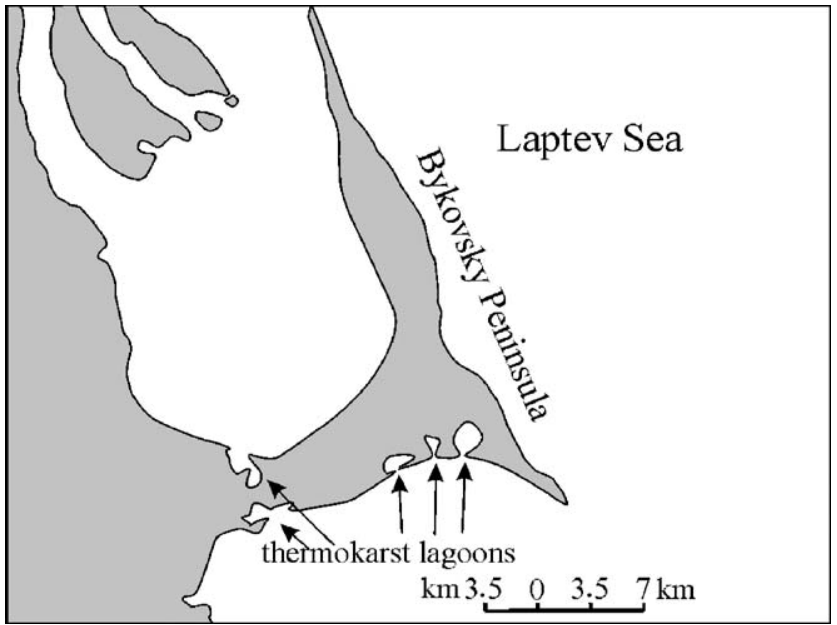

Fig. 6. Bykovskii peninsula - an example of IC island formation. numerous islands and peninsulas composed of the IC sediments. The width of this zone was rather large, and it bordered the strongly dissected coastline. At present, we can observe the final stage of the degradation of the coastal IC. For instance, from the 1930s to the 1950s, the Vasil'evskii and Semenovskii islands were completely destroyed and turned into sandy shoals. The Bykovskii Peninsula is being transformed into an island at present (Fig. 7). The Mostakh, Makar, and Shelonskie isles are on the verge of complete disappearance (Fig. 8). Some parts of the shores where thermokarst lagoons are still preserved to the west of the Yana river mouth. In general, the shoreline has been straightened during the Holocene, which leads to a deceleration of the shoreline retreat. The modern shoreline retreat rate is assessed at $2-6 \mathrm{~m} / \mathrm{yr}$ on the average, and in much higher $(20-30 \mathrm{~m} / \mathrm{yr})$ in some parts of the shore.

The formation of thermokarst lakes changed not only the surface topography of the shelf but also the

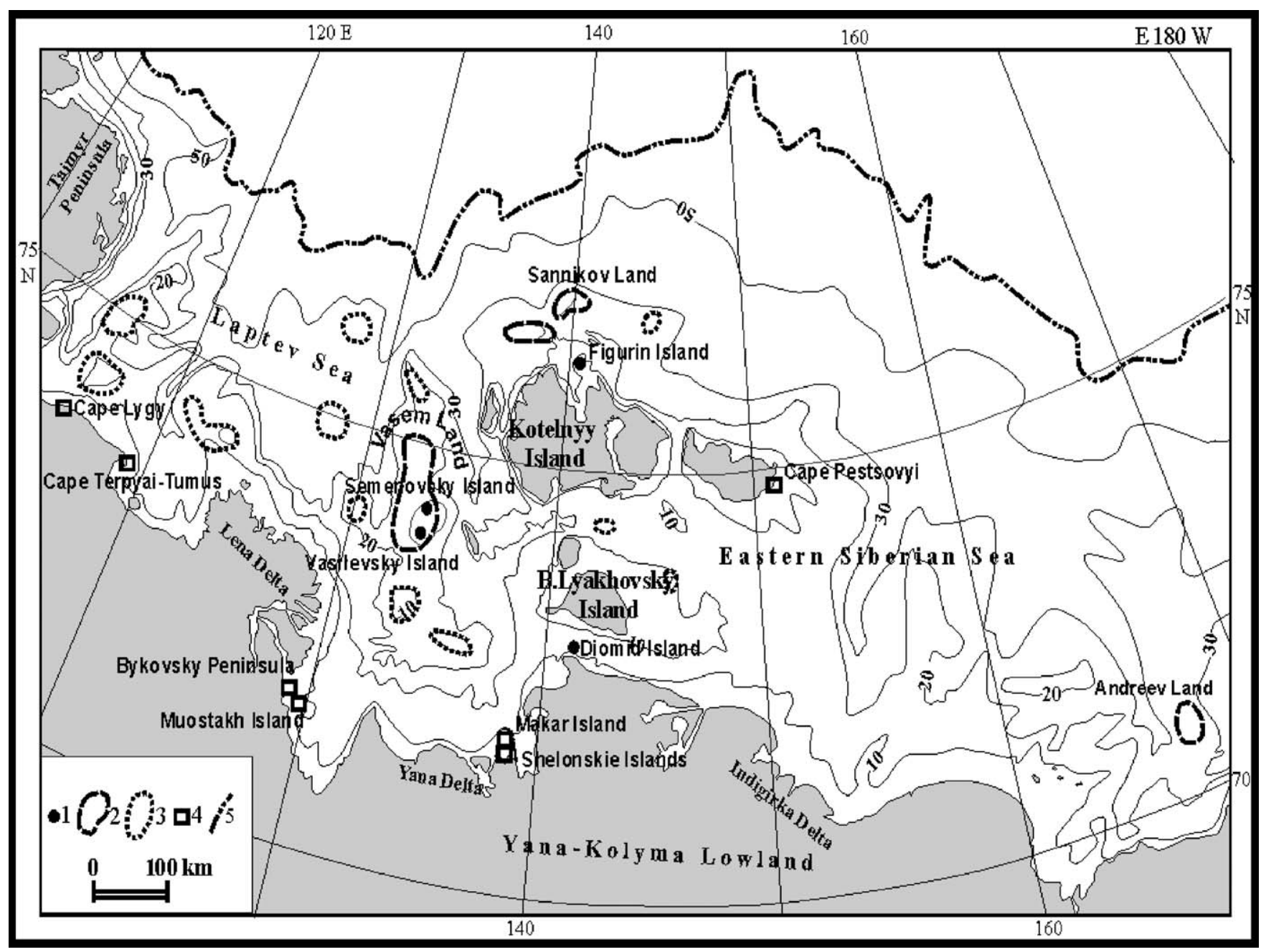

Fig. 7. Schematic map of IC islands: (1) IC islands disappeared, according to historical documents, in the 18-20th centuries; (2) IC islands presumably existing, according to historical documents, 100-250 years ago; (3) IC islands whose location was reconstructed by us from geocryological data (destroyed by thermal abrasion 300-800 years ego); (4) IC islands, islands, and peninsulas being eroded by thermal abrasion in the present time; and (5) shelf edge. 


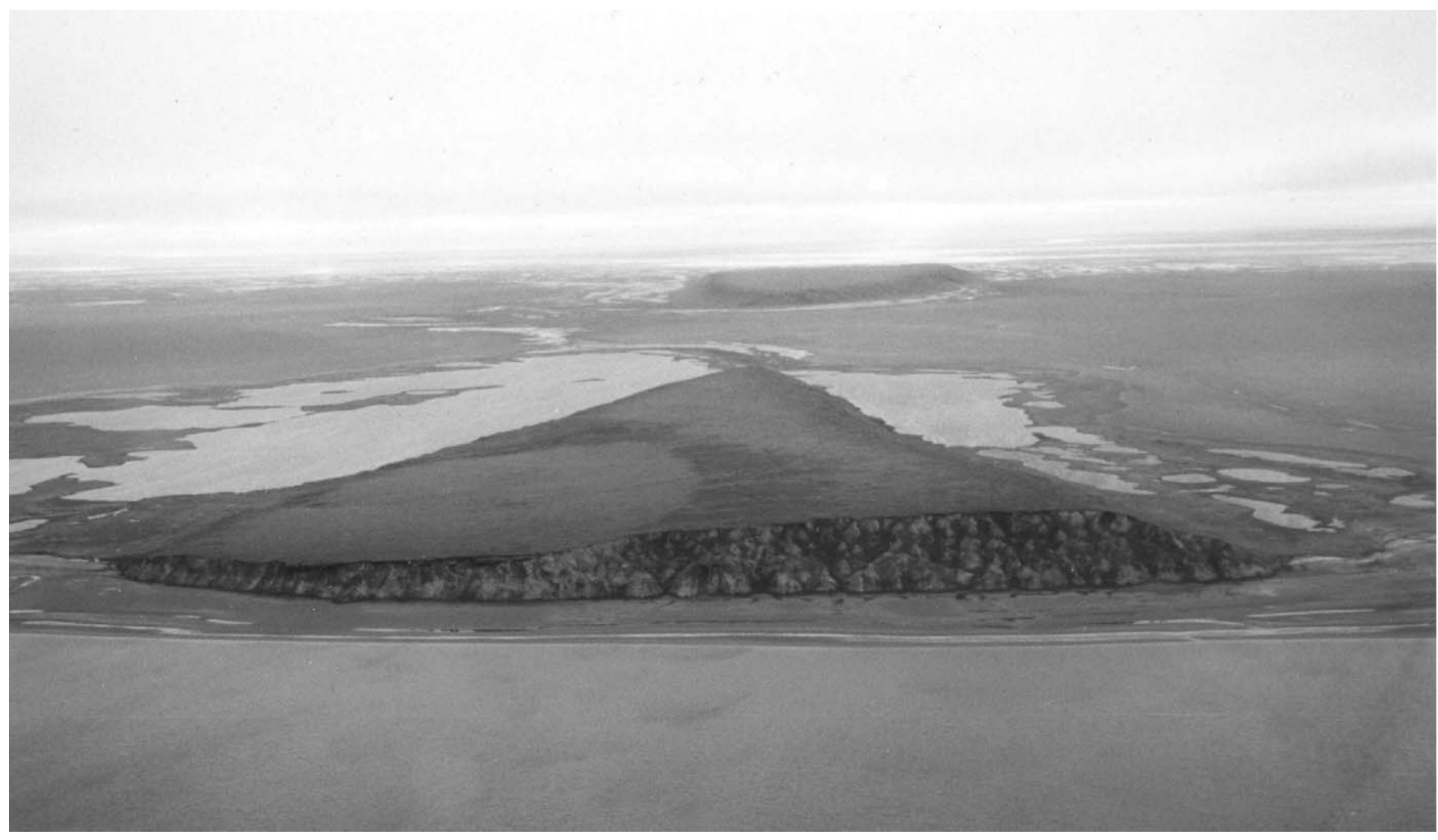

Fig. 8. Overview of Southern Shelonsky IC island (Photo made by V. Tumskoy).

topography of the table of the relic offshore permafrost. Complete thawing of the IC took place under many thermokarst lakes; mineral and organic sediments from IC known under the name of "taberal" deposits in the Russian literature were accumulated on the bottoms of these lakes. Talik zones developed under the lakes. Most of these taliks are closed taliks, because the period of active thawing was not long enough to ensure the formation of open taliks in the low-temperature permafrost with a high ice content.

The progressive development of taliks stopped after the submergence of thermokarst lakes under the sea. Certain depressions in the modern sea bottom described in the literature (Holmes and Creager, 1974) correspond to the former thermokarst lakes. Closed taliks are expected to exist under these depressions. Thus, the former lake taliks have been transformed into submarine taliks. It is important that the deposits within the latter taliks contain some amount of salts. The salinization of the initially fresh-water continental deposits takes place after the transformation of thermokarst lakes into "thermokarst lagoons". This process can be observed within the Ivashkina lagoon on the Bykovskii Peninsula. Some of the submarine taliks have been investigated in the course of the shelf drilling program within the straits of Dmitri Laptev, Sannikov, and Gedenshtrom that separate the New Siberian Islands from one another (Romanovskii et al., 2000). At the same time, sandy bars and shoals exist now in place of the islands that have been completely destroyed by thermal abrasion. These sites are characterized by the presence of frozen continental deposits with a high ice content under a relatively thin layer of unconsolidated cryotic sediments (predominantly sands). These shoals and bars are subjected to an active process of sea floor thermal erosion. Sea floor thermal erosion is an important process that has yet to be studied. At present, we can list the following direct and indirect indications of its activity: (a) the deepening of the sea bottom, (b) the stirring up of bottom sediments, and (c) the discharge of organic detritus into the Arctic seas. The stirring up of sediments composing the bottoms of the Laptev and East Siberian seas leads to a discharge of fine material onto the outer part of the shelf and on the continental slope. Simultaneously, the formation of a layer of coarser (sandy) sediments covering the sea floor on the shoals takes place. The organic constituents of the IC and other Pleistocene deposits preserved in the frozen state in continental deposits are being involved in the carbon cycle. "Sea floor thermal abrasion", along with thermal abrasion of coasts and the discharge of organic matter by rivers, is a process that contributes to the discharge of carbon into the Arctic Ocean. However, the scope and particular mechanisms of this process have yet to be clarified. 
Considering the problem of the effect of lake thermokarst on the transgression, we attempted to estimate the rates of destruction of the IC by thermokarst lakes and the formation of sublacustrine taliks. Calculations were made with due regard to the fact that thawed sediments accumulate on the bottom of thermokarst lakes forming a layer of "taberal" deposits. The accumulation of these deposits slows the further thawing of the IC. Up to the complete thawing of the IC, the depth of the talik zone is restricted to the thickness of the IC. After the complete thawing of the IC, typical lacustrine sediments accumulate on the top of "taberal" deposits; the further thawing affects frozen deposits underlying the IC. The modeling of talik formation under thermokarst lakes has shown that most of these taliks should be closed even with the most favorable conditions of thawing. There is not enough time for them to be transformed into open taliks, even under large and long-existing thermokarst lakes on coastal lowlands with the temperature of bottom sediments about $+2.0^{\circ} \mathrm{C}$. This conclusion has changed our previous views about the presence of open taliks under large thermokarst lakes within the shelf and coastal lowlands (Geocryology of the USSR, 1989). However, the existence of open taliks is possible under the lakes allocated to rift zones with the geothermal flux values exceeding $70-80 \mathrm{~mW} / \mathrm{m}^{2}$, where the thawing of permafrost from the bottom could take place.

Within the shelf, the progressive development of taliks stopped after their submergence under saline seawater with subzero temperatures. Moreover, the transition of lake taliks composed of clayey slightly permeable freshwater sediments into the submerged state leads to their partial freezing and the formation of submarine frostheaving mounds (pingos or bulgunnyakhs). Thus, most of the taliks within coastal lowlands and the inner part of the shelf are closed taliks, and the permafrost has a continuous character, representing an impermeable layer of uneven thickness. This frozen layer is impermeable for ground (sub-permafrost) water and gases. According to the results of modeling, we can expect the existence of a thick of gas hydrates stability zone (GHSZ) of the methane group under the permafrost within coastal lowlands and the inner part of the shelf (Romanovskii and Hubberten, 2001). Thus, permafrost serves as a barrier preventing the emission of greenhouse gases from deep layers within the vast territory of the Arctic shelf in the Laptev and East Siberian seas. In the inner part of the shelf (down to the isobaths of 50-60 m) and within the coastal lowlands, this barrier has existed continuously for at least $400 \mathrm{ka}$ (Romanovskii and Hubberten, 2001).

The transformation of numerous thermokarst lakes into "thermokarst lagoons", followed by the transformation of lake taliks under the lakes into submarine taliks leads to the salinization of fresh-water continental deposits under the effect of seawater. This process leads to changes in geochemical and physical properties of the deposits; it may favor the preservation of organic compounds in the "taberal", lacustrine and lagoon deposits. However, geochemical processes accompanying the transformation of fresh-water continental deposits into the submarine state are virtually unknown. Moreover, it is not easy to identify these deposits, because they possess the properties typical of both the fresh-water continental and the marine sediments. Meanwhile, these partly transformed deposits should be widespread on the shelf, coastal lowlands, and Arctic islands. In this context, their stratigraphic significance, as well as their meaning for engineering purposes can hardly be overestimated.

\section{Conclusions}

(1) Relic offshore permafrost exists within the vast Arctic shelf in Eastern Siberia. This permafrost has a continuous character within the inner part of the shelf (to sea depths of about $60 \mathrm{~m}$ ) and a discontinuous character at greater sea depths (down to the transition from the shelf to the continental slope).

(2) The average thickness of permafrost within most of the shelf is estimated at $300-350 \mathrm{~m}$; maximum values (500 $\mathrm{m}$ and more) are typical of the shoals near the Kotel'nyi Island.

(3) The thawing of relic offshore permafrost proceeds mostly from the bottom under the impact of the geothermal heat flux; permafrost thawing from the top is hampered by subzero temperatures of seawater near the sea floor; these temperatures are constantly maintained owing to specific hydrological processes in the Arctic seas.

(4) Relic offshore permafrost within the largest part of the shelf is ice bearing and has temperatures close to the range of freezing-thawing processes. Ice bonded permafrost is only preserved within the areas of recently abraded islands composed of the Ice Complex (IC) sediments.

(5) Temperature and pressure conditions beneath the permafrost within the coastal lowlands and shelf correspond to the zone of stability of gas hydrates.

(6) An important role in the last (Holocene) transgression of the sea played the process of lake thermokarst. The formation of thermokarst lakes started on the shelf and coastal lowlands before the submergence of the shelf. Therefore, the transgressing sea first inundated the depressed elements of coastal topography, i.e., thermokarst lakes and drained thermokarst depressions (alases) transforming them into "thermokarst lagoons". The residual elevations separating these "lagoons" and composed of the IC sediments were subjected to thermal 
abrasion. Thus, the IC islands composed of the IC deposits were formed and then destroyed. This sequence of environmental events favored a very rapid submergence of the vast East Siberian shelf under the transgressing sea.

(7) Most of the taliks under numerous thermokarst lakes on coastal lowlands and within the shelf are closed taliks. Thus, the permafrost has a continuous character and, together with the gas hydrates stability zone, prevents the emission of gases from deep layers beneath the permafrost.

(8) Taliks on the shelf were initially formed as lake taliks and then transformed into submarine taliks. The latter are marked by deep (100 $\mathrm{m}$ and more) depressions in the table of the relic offshore permafrost. The places with a shallow permafrost table correspond to the shoals and sandbanks marking the former locations of recently abraded islands composed of the IC deposits. These are two extreme variants of the relic offshore permafrost. There are numerous transitional variants, when the permafrost is overlain by a layer of variable thickness composed of partially thawed sediments and Holocene marine deposits. Sandbanks in places of the islands destroyed by the shore thermal abrasion are subjected at present to the sea floor thermal abrasin. The latter is widespread within shallow-water areas of the East Siberian shelf down to the sea depths of $20-25 \mathrm{~m}$, or even more.

\section{Acknowledgements}

This study has been supported by the Russian Foundation for Basic Research (Grant nos. 97-0564206 and 00-05-64430), joint Russian-German programs "Laptev Sea System" and "Laptev Sea System 2000," OSL, and the National Science Foundation (USA) Grant no. 0PP 9986 826. The authors express their special gratitude for constant support and valuable scientific consultations to Drs. S.S. Drachev, I.A. Dmitrenko, and A.V. Sher.

\section{References}

Balobaev, V.T., 1991. Geothermic Conditions of the Permafrost in Northern Asia. Nauka, Novosibirsk, p. 193 (in Russian).

Bauch, H.A., Kassens, H., Erlenkeuser, Grootes, P.M., Thiede, J., 1999. Depositional environment of the Laptev Sea (Arctic Siberia) during the Holocene. BOREAS 28 (1), 194-204.

Chappell, J., Dhacleton, N.J., et al., 1996. Reconciliation of Late Quaternary sea level derived from coral terraces at Huon Peninsula with deep sea oxygen isotope records. Earth and Planetary Science Letters $141,227-236$.
Churun, V.N., Timochov, L.A., 1995. Cold Bottom Water in the Southern Laptev Sea. Reports of Polar Research 176, 107-114.

Drachev, S.S., Jonson, G.L., Laxon, S.W., MacAdoo, D.C., Kassens, H., 1999. Main structural elements of eastern Arctic continental margin derived from satellite gravity and multichannel seismic reflection data. In: Kassens, H., Bauch, H.A., Dmitrienko, I.A., Eicken, H., Hubberten, H.W., Mellis, M., Thiede, J., Timokhov, L.A. (Eds.), Land-Ocean Systems in the Siberian Arctic. Dynamics and History. Springer, Berlin, pp. 667-682.

Gavrilov, A.V., Tumskoy, V.E., 2000. The evolution of the mean annual ground temperature on coastal lowlands in middle and Late Pleistocene. Earth Cryosphere 3, 3-16 (in Russian).

Gavrilov, A.V., Romanovskii, N.N., Romanovsky, V.E., Hubberten, H.-W., 2001. Offshore permafrost distribution and thickness in the eastern region of Russian Arctic. In: Semiletov, I.P. (Ed.), Changes in the Atmospheric-Land-Sea System in the American Arctic. Proceeding of the Arctic Regional Centre. Dalnauka, Vladivostok, pp. 209-218.

Geocryology of the USSR, 1989. Eastern Siberia and the Far East. Nedra, Moscow, p. 515 (in Russian).

Ershov, E.D. (Ed.), 1996. Geocryological Map of the USSR, 1:2,500,000 Scale. Moscow State University, Moscow (in Russian).

Fairbanks, R.J., 1989. A 17,000-years glacio-eustatic sea level record: influence of glacial melting rates on the Younger Dryas event and deep ocean circulation. Nature 342, 637-642.

Hinz, K., Delisle, G., Block, M., 1998. Seismic evidence for the depth extent of permafrost in shelf sediments of the Latev Sea, Russian Arctic. In: Permafrost. Seventh International Conference Proceedings, Yellowknife, Canada, pp. 453-459.

Holmes, M.L., Creager, J.S., 1974. Holocene History of the Laptev Sea Continental Shelf, Marine Geology and Oceanology of the Arctic Seas. Springer, Berlin, pp. 210-229.

Kaplina, T.N., Lozhkin, A.I., 1979. The age of alas sediments in the coastal lowland of Yakutia. Izvestiya Akademii Nauk SSSR, Seriya Geologicheskaya 2, 69-75 (in Russian).

Kassens, H., Bauch, H., Drachev, S., 2000. The Transdrift VIII expedition to the Laptev Sea: the shelf Drilling campaign of Laptev Sea System 2000. In: Proceedings of the Sixth Workshop on Russian-German Cooperation: Laptev Sea System, St. Petersburg. Program and Abstracts, pp. 39-40.

Lysak, S.V., 1988. Geothermal Heat Flux of Continental Rifts. Nauka, Moscow, p. 148 (in Russian).

Petit, J.R., Jouzel, J., Raynaud, D., et al., 1999. Climate and atmospheric history of the past 420000 years from the Vostok ice core, Antarctica. Nature 399, 429-436.

Romanovskii, N.N., Hubberten, H.-W., Gavrilov, A.V., Tumskoy, V.E., 1998a. Like thermokarst and its role in a formation of coastal zone in the Laptev Sea. Earth Cryosphere 3, 79-91 (in Russian).

Romanovskii, N.N., Gavrilov, A.V., Kholodov, A.L., et al., 1998b. The forecasting map of Laptev sea shelf off-shore permafrost. In: Permafrost. Seventh Permafrost International Conference Proceedings, Yellowknife, Canada, pp. 967-972.

Romanovskii, N.N., Hubberten, H.-W., 2001. Results of permafrost modelling of the lowlands and shelf of Laptev Sea region, Russia. Permafrost and Periglacial Processes 12, 191-202.

Romanovskii, N.N., Gavrilov, A.V., Tumskoy, V.E., 1999. Lake thermokarst and its role in a formation of coastal zone in Laptev Sea. Earth Cryospher 3, 79-91.

Romanovskii, N.N., Hubberten, H.-W., Gavrilov, A.V., Tumskoy, V.E., Grigoriev, M.N., Tipenko, G.S., Siegert, Ch., 2000. Thermokarst and land-ocean interactions, Laptev sea region, Russia. Permafrost and Periglacial Processes 11, 137-152.

Tipenko, G.S., Romanovskii, N.N., Kholodov, A.L., 1999. Simulation of the offshore permafrost and gas hydrate stability zone; mathematical solution, numerical realisation and records of test calculation. Earth Cryospher 3, 71-78 (in Russian). 
Tipenko, G.S., Romanovskii, N.N., Kholodov, A.L., 2001. Simulation of the offshore permafrost and gas hydrate stability zone: mathematical solution, numerical realisation and preliminary results. Polarforshung 69, 229-234.

Tumskoy, V.E., 2002. Thermokarst and its role in the development of the Laptev sea region in the late Pleistocene and Holocene (authors' abstract of the Candidate Sci. (Geol.) Dissertation). Moscow State University, Moscow, p. 26 (in Russian). Veselov, O.V., Lipina, E.N., 1983. Catalogue Data of Geothermal Heat Flux in East of Asia, Australia and west of Pacific. FEScS of USSR Sc.A. Publishers, Vladivastok, p. 160 (in Russian). 